\title{
ANALISIS PENERAPAN METODE INDEX CARD MATCH DALAM PEMBIASAAN LITERASI BAHASA PRODUKTIF SISWA SEKOLAH DASAR
}

\section{Arik Umi Pujiastuti}

Universitas PGRI Ronggolawe, Indonesia

Email: arik.umi86@gmail.com

\begin{tabular}{|c|c|}
\hline Info Artikel & Abstract \\
\hline $\begin{array}{l}\text { Sejarah Artikel: } \\
\text { Diserahkan } 18 \text { Juni } 2020 \\
\text { Direvisi } 16 \text { November } 2020 \\
\text { Disetujui } 16 \text { November } 2020\end{array}$ & $\begin{array}{l}\text { The research carried out aims to describe the results of the productive language literacy of } \\
\text { grade } 1 \text { primary school students by applying the index card match method and the results } \\
\text { of student responses. } \\
\text { The type of research used is Classroom Action Research which consists of two cycles. The } \\
\text { subjects of this study were students of grade } 1 \text { SDN Panyuran 1, Palang District, Tuban } \\
\text { Regency. Data collection techniques using test techniques, questionnaires, and } \\
\text { documentation. The research instruments used included test sheets, questionnaires. The } \\
\text { data analysis technique used is descriptive quantitative. } \\
\text { Based on the results of research, the results of productive language skills of students in } \\
\text { grade } 1 \text { primary school in the first cycle were } 67.26 \% \text { and } 87.2 \% \text { in the second cycle. The } \\
\text { results of student' responses given at the end of the cycle of } 98.56 \% \text { are classically. }\end{array}$ \\
\hline
\end{tabular}

\begin{abstract}
Abstrak
Penelitian yang dilakukan bertujuan mendeskripsikan hasil literasi bahasa produktif siswa kelas 1 SD dengan penerapan metode index card match dan hasil respon siswa.

Jenis penelitian yang digunakan adalah Penelitian Tindakan Kelas yang terdiri dari dua siklus. Subjek penelitian ini adalah siswa siswa kelas 1 SDN Panyuran 1 Kecamatan Palang Kabupaten Tuban. Teknik pengumpulan data menggunakan teknik tes, angket, dan dokumentasi. Instrumen penelitian yang digunakan meliputi lembar tes, angket. Teknik analisis data yang digunakan adalah deskriptif kuantitatif.

Berdasarkan hasil penelitian hasil kemampuan bahasa produtif siswa kelas 1 SD pada siklus I secara klasikal sebesar $67,26 \%$ dan siklus II $87,2 \%$. Hasil respon siswa yang diberikan pada akhir siklus sebesar $98,56 \%$ secara klasikal.
\end{abstract}




\section{PENDAHULUAN}

Manusia sebagai makhluk sosial selalu melakukan interaksi dan komunikasi dengan manusia lain salah satunya dalam kegiatan pembelajaran. Pembelajaran merupakan kegiatan yang dilakukan siswa dengan guru maupun siswa dengan siswa. Berdasarkan kurikulum 2013 kompetensi inti yang harus miliki siswa ada empat yaitu, KI 1 memiliki sikap spiritual, KI 2 sosial, KI 3 pengetahuan faktual, dan KI 4 keterampilan berdasarkan pengetahuan faktual. Tujuan pada KI 4 siswa diharapkan dapat mengomunikasikan secara lisan ataupun tulisan berdasarkan pengetahuan faktual yang telah dikuasai melalui kegiatan mengamati, menanya, mencoba, dan mengasosiasi. Untuk mencapai kompetensi tersebut maka pembelajaran tidak hanya berorientasi pada hafalan teori atau konsep pada materi tema namun, diaplikasikan melalui pengalaman langsung yang biasa disebut literasi. Sejalan dengan pendapat Sintia, et al., (2018) bahwa proses pembelajaran harus berkaitan dengan apa yang dikerjakan oleh siswa dan mampu membuat siswa mengerti dan memahami apa yang mereka terima dalam kegiatan belajar.

Harapan tersebut tidak sesuai dengan kondisi di lapangan. Masih banyak ditemui pembelajaran yang bersifat konvensional dengan hanya berorientasi pada penguasaan materi pembelajaran. Adanya hal tersebut hendaknya menjadikan perubahan mindset bagi para pelaku pendidikan supaya dapat merancang pembelajaran sebagai kegiatan yang menyenangkan bagi siswa dan mereka dapat terlibat langsung melalui pembelajaran literasi. Berdasarkan penelitian yang dilakukan Susanto (2016) menyatakan bahwa literasi merupakan kemampuan yang dimiliki seseorang dalam menyerap informasi dan merekontruksi kembali atau menyusun kembali informasi yang didapatkan berdasarkan kegiatan membaca dan menulis yang dilakukannya. Berdasarkan penelitian terdahulu kegiatan literasi berbahasa dapat dilakukan melalui kegiatan pembelajaran karena dengan terbiasa melakukan literasi siswa akan belajar dan berlatih secara aktif untuk mengomunikasikan gagasan dan idenya melalui berbicara dan menulis (Syaifulloh, et al., 2018).

Dalam melakukan kegiatan tersebut bahasa memiiki peran yang sangat penting yaitu, sebagai alat atau media yang digunakan (Fakhiroh, 2018). Hal senada disampaikan oleh Fardani dan Wiranti (2019) bahasa merupakan alat komunikasi utama manusia yang memiliki beragam karakteristik. Bahasa sebagai alat komunikasi bahasa terdiri dari empat kemampuan yaitu, menyimak, berbicara, membaca, dan menulis. Berdasarkan kemampuan tersebut maka jenis bahasa diklasifikasi menjadi dua yaitu, bahasa reseptif dan produktif. Hasil penelitian yang dilakukan Sardila (2015) menjelaskan bahwa, dalam konteks komunikasi yang baik seseorang harus memiliki kemampuan reseptif dan produktif dengan baik pula sehingga komunikasi dapat berjalan dengan kondusif.

Deskripsi bahasa reseptif adalah kemampuan berbahasa yang bersifat menerima yaitu, menyimak dan membaca, sedangkan bahasa produktif adalah, kemapuan seseorang dalam berbahasa yang bersifat menghasilkan bahasa, baik lisan ataupun tulisan yaitu pada aktivitas berbicara dan menulis (Atiqoh, 2018). Hal tersebut sesuai dengan penelitian yang dilakukan Darwati (2016) bahwa bahasa memiliki sifat reseptif dan produktif di mana bahasa produktif ditunjukkan melalui aktivitas berbicara dan menulis.

Kemampuan dalam bahasa produktif merupakan kemampuan berbahasa yang harus dikuasai siswa sejak dini karena, dengan menguasai kemampuan tersebut seseorang dapat mengungkapkan ide, pikiran dan gagasan baik secara tertulis maupun secara lisan. Berdasarkan urutan kemampuan bahasa, berbicara merupakan kemampuan awal yang dikuasai seorang siswa karena, sebelum masuk sekolah mereka belajar berbahasa dari lingkungan terdekatnya (Hasanah, et al., 2019). Menulis sebagai salah satu kemampuan bahasa produktif yang dikuasai siswa paling akhir karena siswa baru mengembangkan kemampuan tersebut saat masuk dunia sekolah. Hal tersebut dikuatkan oleh pendapat Triaji, et al. (2019) bahwa penguasaan empat kemampuan berbahasa yang dimiliki seorang siswa itu memiliki jenjang dan tahapan yaitu, berbicara baru menulis.

Berbicara sebagai salah satu kemampuan produktif adalah, kemampuan seseorang dalam mengartikulasikan lambang bunyi yang bertujuan menyampaikan perasaan dan gagasan kepada orang lain Fakhiroh (2018). Sedangkan, menulis sebagai kemampuan akhir merupakan aktivitas yang harus dikembangkan sejak dini karena menurut Setiawan, et al. (2019) menulis merupakan kemampuan produktif di mana dapat menghasilkan sebuah karya yang dapat mengembangkan kreativitas dan kemampuan berpikir kritis bagi siswa Sekolah Dasar (SD) dalam mengikuti pembelajaran.

Kurikulum sebagai dasar yang digunakan dalam pelaksanaan pembelajaran di tingkat satuan pendidikan termasuk di SD. Berdasarkan 
UU sisdiknas tahun 2013 kurikulum 2013 yang saat ini digunakan di SD adalah bertujuan mengembangkan hardskills dan softskills bagi siswa (Tryanasari, 2017). Oleh sebab itu pembelajaran yang dilakukan harus memperhatikan tingkat perkembangan siswa SD. Menurut Piaget tahap perkembangan siswa SD adalah tahap operasional konkret. Ditambahkan oleh Mulyo (2017) masa anak usia sekolah dasar termasuk masa emas di mana perkembangan sangat pesat sehingga pembelajaran memiliki peran penting dalam kehidupan anak dan literasi merupakan budaya yang dapat digunakan untuk mencapai tujuan yang diinginkan dalam pembelajaran.

Berkaitan dengan kegiatan pembelajaran, guru memiliki peran penting dalam menentukan metode pembelajaran yang dapat merangsang siswa untuk melakukan budaya literasi bahasa produktif. Pemilihan metode harus disesuaikan dengan tujuan pembelajaran yang dicapai dan tujuan kurikulum secara umum yaitu menjadikan siswa aktif dan terlibat langsung dalam kegiatan pembelajaran (melakukan literasi). Salah satu metode pembelajaran aktif yang dapat digunakan adalah metode Index Card Match.

Suprijono (2013) menjelaskan bahwa Index Card Match (mencari pasangan kartu) adalah suatu metode yang cukup menyenangkan digunakan untuk mengembangkan kemampuan siswa terhadap materi yang dipelajari. Adapun penelitian lain dilakukan oleh Silberman (2016) bahwa Index Card Match merupakan cara aktif dan menyenangkan untuk dapat meningkatkan keterampilan siswa. Hal senada juga disampaikan oleh Yanti (2019) dalam penelitiannya menjelaskan bahwa Index Card Match dapat meningkatkan interaksi dan keaktifan siswa dalam berkolaborasi dengan teman lainnya. Penelitian lain juga dilaksanakan oleh Darojah (2018) dimana hasil yang didapatkan menjelaskan bahwa Index Card Match adalah salah satu metode yang bisa digunakan guru dalam pembelajaran yang mengaktifkan siswa dengan teman lainnya. Pendapat lainnya juga dikemukakan dalam penelitian Rambe (2018) bahwa Index Card Match adalah salah satu metode yang dapat digunakan dalam pembelajaran bahasa. Penerapan metode Index Card Match diharapkan dapat mengaktifkan siswa dalam kegiatan pembelajaran, khususnya dalam kemampuan literasi bahasa produktif.

Tujuan penelitian ini adalah mendeskripsikan kemampuan literasi bahasa produktif siswa SD. Berdasarkan kajian dari penelitian-penelitian terdahulu maka metode Index Card Match dapat dditerapkan dalam kegiatan pembelajaran untuk pembiasaan literasi bahasa produktif bagi siswa SD.

\section{METODE PENELITIAN}

Penelitian ini merupakan penelitian tindakan kelas (PTK) atau Classroom Action Research (CAR) yang bertujuan meningkatkan atau memperbaiki praktik pembelajaran. Prosedur penelitian tindakan kelas menurut Arikunto, et al. (2015) meliputi empat tahap yaitu, perencanaan, pelaksanaan, pengamatan, dan refleksi yang disajikan pada Gambar 1 berikut.

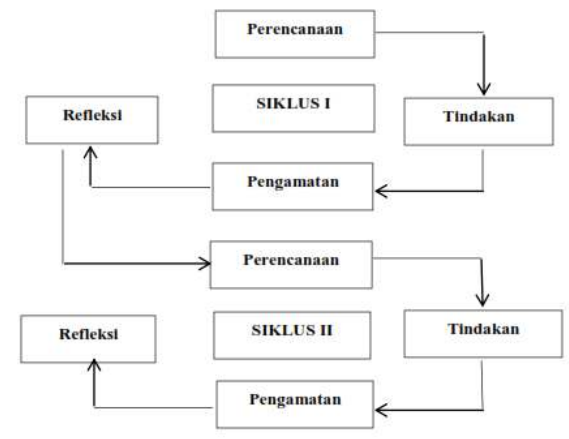

Gambar 1. Tahap Penelitian Tindakan Kelas (Arikunto, et al., 2015)

Penelitian ini dilaksanakan di SDN Payuran 1 Kecamatan Palang Kabupaten Tuban. Subjek penelitian ini adalah siswa siswa kelas 1 SDN Panyuran 1 Kecamatan Palang Kabupaten Tuban. Teknik pengumpulan data menggunakan teknik tes, angket, dan dokumentasi. Instrumen penelitian yang digunakan meliputi lembar tes, angket. Teknik analisis data yang digunakan adalah deskriptif kuantitatif.

\section{HASIL DAN PEMBAHASAN Literasi Bahasa Produktif}

Literasi bahasa produktif dalam penelitian ini menurut Pujiastuti (2018) sebagai aktivitas yang dilakukan seseorang dalam membuat kode (Encode) sehingga mengahsilkan sebuah bahasa. Data literasi Bahasa produktif dilihat dari kemampuan berbicara dan menulis siswa. Hasil literasi bahasa produktif pada prasiklus yang disajikan dalam bentuk diagram pada Gambar 2 berikut. 


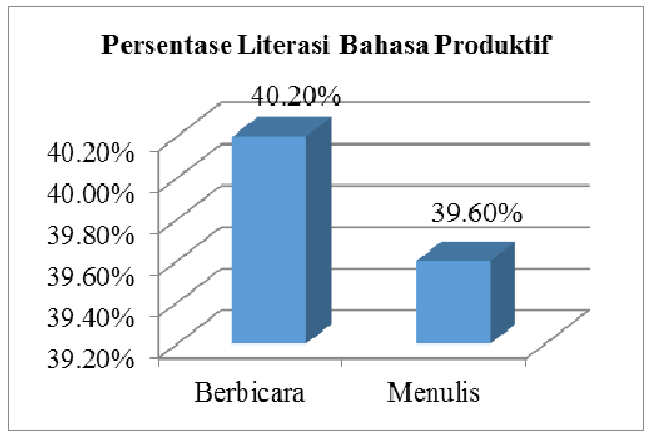

Gambar 2. Diagram Persentase Literasi Bahasa Produktif Pra Siklus

Berdasarkan Gambar 2 diketahui bahwa kemampuan berbicara sebanyak $40,20 \%$ dengan kriteria rendah dan menulis sebanyak $39,60 \%$ termasuk kriteria rendah. Rata-rata persentase kemampuan bahasa produktif hanya mencapai $39,6 \%$ dengan kriteria rendah. Haisl tersebut masih belum mencapai indikator keberhasilan yaitu $\geq 70 \%$. Berdasarkan data tersebut maka masalah pembelajaran perlu diberikan solusi pemecahan yaitu dengan penerapan metode Index Card Match. Hasil literasi bahasa produktif pada siklus I dengan penerapan metode Index Card Match disajikan dalam Gambar 3 berikut ini.



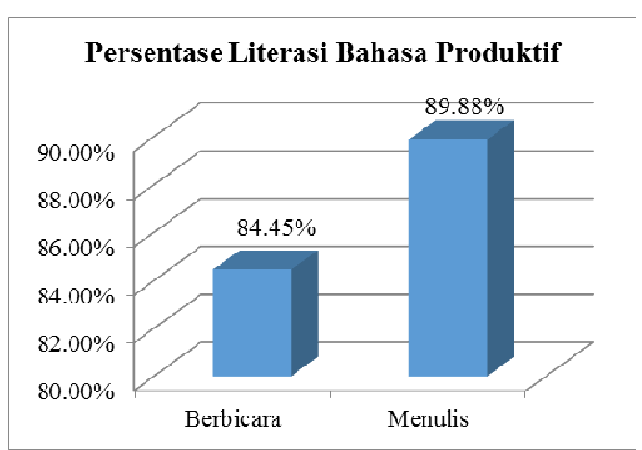

Gambar 4 . Diagram Persentase Literasi Bahasa Produktif Siklus II

Pada Gambar 4 diketahui bahwa terjadi peningkatan kemampuan menulis sebesar $89,88 \%$ dan kemampuan berbicara sebesar $84,45 \%$. Rata-rata persentase sebesar $87,16 \%$ dan sudah mencapai indikator keberhasilan yang ditetapkan. Rekapitulasi peningkatan literasi bahasa produktif disajikan dalam Tabel 1 berikut.

Tabel 1. Peningkatan Pembiasaan Literasi

\begin{tabular}{ccccc}
\hline \multirow{2}{*}{ No } & Kemampuan & \multicolumn{3}{c}{ Persentase Peningkatan } \\
\cline { 3 - 5 } & Prasiklus & $\begin{array}{c}\text { Siklus } \\
\text { I }\end{array}$ & $\begin{array}{c}\text { Siklus } \\
\text { II }\end{array}$ \\
\hline 1. & Berbicara & $40,2 \%$ & $63,99 \%$ & $84,45 \%$ \\
\hline 2. & Menulis & $39,6 \%$ & $70,54 \%$ & $89,88 \%$ \\
\hline & $\begin{array}{c}\text { Persentase } \\
\text { Klasikal }\end{array}$ & $39,9 \%$ & $67,26 \%$ & $87.2 \%$ \\
\hline
\end{tabular}

Data pada Tabel 1 menunjukkan adanya peningkatan kemampuan berbicara dan menulis dari prasiklus sampai pada siklus II. Susanto (2016) menyatakan bahwa kegiatan nyata yang dilakukan seseorang yang berkaitan dengan konteks bahasa, dengan demikian literasi sangat erat kaitannnya dengan bahasa produktif. Bahasa produktif senndiri adalah bahasa yang menghasilkan suatu produk berupa lisan dan tulisan meliputi kemampuan berbicara dan menulis (Ahsin,2016). Hasil penelitian ini juga didukung oleh pendapat Ristiyani, et al. (2017) bahwa pengemasan sumber pembelajaran yang menarik akan memberikan pengaruh yang positif terhadap keterampilan membaca dan menulis.

Tabel 1 menunjukkan bahwa terdapat peningkatan kemampuan menulis dan berbicara pada prasiklus, siklus I dan siklus II. Peningkatan ini terjadi karena penggunaan metode index card match. Penerapan index card match pada siklus I mengalami peningkatan dibandingkan dengan pra siklus, namun persentase yang diperoleh masih belum memenuhi indikator yang ditetapkan. Setelah penelitian lanjut siklus II 


\begin{abstract}
Arik Umi Pujiastuti
ANALISIS PENERAPAN METODE INDEX CARD MATCH DALAM PEMBIASAAN LITERASI ...

REFLEKSI EDUKATIKA : Jurnal Ilmiah Kependidikan, Volume 11, Nomor 1, Desember 2020, hlm. 96-101
\end{abstract}

terdapat peningkatan kembali yaitu, menulis $84,45 \%$ kriteria tinggi berbicara $89,88 \%$ kriteria sangat tinggi. Data tersebut menunjukkan bahwa pada siklus II pencapaian yang didapatkan sudah sesuai dengan indikator ketetapan dan index card match dapat meningkatkan pembiasaan literasi bahasa produktif pada siswa SD. Hasil penelitian ini selaras dengan hasil penelitian yang dilakukan Suwartiani (2017) bahwa pembelajaran dengan menggunakan metode Index Card Match dapat memberikan peningkatan pada hasil belaar siswa SD VI. Penerapan metode Index Card Match dapat meningkatkan aktivitas siswa dalam memasangkan kartu. Aktivitas siswa yang meningkat berpengaruh positif terhadap peningkatan hasil belajar siswa. Sejalan dengan pendapat Wati, et al. (2015) bahwa siswa yang aktif dalam kegiatan pembelajaran akan memiliki hasil belajar yang baik.

\section{Respon Siswa}

Data respon siswa diperoleh melalui angket respon siswa terhadap penggunaan metode Index Card Match. Angket respon siswa diberikan kepada siswa pada akhir siklus II. Rekapitulasi hasil respon siswa terhadap penerapan metode Index Card Match disajikan dalam siswa disajikan dalam Tabel 2 berikut.

Tabel 2. Rekapitulasi respon siswa

\begin{tabular}{clcc}
\hline No & \multicolumn{1}{c}{ Pernyataan } & \multicolumn{2}{c}{ Jawaban (\%) } \\
Ya & Tidak \\
\hline 1 & $\begin{array}{l}\text { Cara belajar yang baru saja } \\
\text { berlangsung sangat menarik }\end{array}$ & 100 & 0 \\
2 & $\begin{array}{l}\text { Pembelajaran dengan kartu } \\
\text { membuat saya semakin }\end{array}$ & 96,4 & 3,6 \\
& $\begin{array}{l}\text { aktif bertanya kepada guru } \\
\text { Dengan pembelajaran kartu } \\
\text { membuat saya lebih mudah } \\
\text { mengerjakan soal dari guru }\end{array}$ & 100 & 0 \\
4 & $\begin{array}{l}\text { Saya ingin topik lain } \\
\text { diajarkan seperti ini }\end{array}$ & \\
5 & $\begin{array}{l}\text { Saya lebih suka belajar } \\
\text { berpasangan } \\
\text { belajar sendiri daripada }\end{array}$ & 100 & 0 \\
\hline & Persentase Klasikal & $\mathbf{9 8 , 5 6}$ & $\mathbf{1 , 4 4}$ \\
\hline
\end{tabular}

Berdasarkan Tabel 2 menunjukkan bahwa penerapan metode Index Card Match mendapatkan respon baik dari siswa. Keseluruhan siswa menyatakan bahwa penerapan metode Index Card Match menarik dan mempermudah siswa dalam mengerjakan soal. Siswa juga menyatakan bahwa belajar dengan menggunakan metode Index Card Match menjadikan siswa lebih aktif karena belajar secara berpasangan. Rata-rata respon positif siswa terhadap pembelajaran dengan metode Index Card Match sebesar 98,56\% dengan kriteria sangat tinggi sehingga hal ini berdampak pada meningkatnya pembiasaan literasi bahasa produktif siswa. Berdasarkan data tersebut dapat dikatakan bahwa bahasa produktif berperan penting dalam sebuah pembelajaran. Pembiasaan literasi yang baik dapat menciptakan komunikasi lisan dan tulisan dengan baik.

\section{SIMPULAN}

Pembiasaan literasi bahasa produktif siswa mengalami peningkatan pada siklus I sebesar $67,26 \%$ berdasarkan persentase kemampuan berbicara $70,54 \%$ dan menulis $63,9 \%$. Pada siklus II meningkat menjadi $87,2 \%$ dengan rincian berbicara $89,88 \%$ dan menulis $84,45 \%$. Adapun peningkatan persentase pembiasaan literasi bahasa produktif dari siklus I ke siklus II sebesar 47,3\%. Respon positif siswa dengan pembelajaran menggunakan metode Index Card Match sebesar 98,56\% pada kriteria sangat tinggi.

\section{DAFTAR PUSTAKA}

Ahsin, Muhammad Nur. 2016. Peningkatan Keterampilan Menulis Karangan Narasi Dengan Menggunakan Media Audiovisual Dan Metode Quantum Learning. REFLEKSI EDUKATIKA : Jurnal Ilmiah Kependidikan, 6 (2): 158171.

Arikunto, Suharsimi., et al. 2015. Penelitian Tindakan Kelas. Jakarta: PT Bumi Aksara

Atiqoh, Farhatul. 2018. Teknik Maudhu'Usbu'iy Sebagai Alternatif Untuk Meningkatkan Penguasaan Keterampilan Reseptif Dan Produktif Bahasa Arab. Prosiding Seminar Nasional Bahasa arab Mahasiswa II Tahun 2018, 197-212

Darwati. 2016. Kesalahan Berbahasa Produktif Guru-guru TK Di Kecamatan Sambeng. Jurnal EDU-KAT, 3 (1): 19-28.

Fakhiroh, Ani. 2018. Pengaruh Percaya Diri Terhadap Keterampilan Berbicara. Jurnal El-Ibtikar, 7 (1): 34-46.

Fardani, Much Arsyad., dan Wiranti, D.A. 2019. Bentuk dan Proses Pembentukan Bahasa 
Arik Umi Pujiastuti

ANALISIS PENERAPAN METODE INDEX CARD MATCH DALAM PEMBIASAAN LITERASI ...

REFLEKSI EDUKATIKA : Jurnal Ilmiah Kependidikan, Volume 11, Nomor 1, Desember 2020, hlm. 96-101

Prokem Pada Pekerja Manyeng Di Desa Garung Lor Kecamatan Kaliwungu Kabupaten Kudus. KREDO : Jurnal Ilmiah Bahasa dan Sastra, 2 (2): 368-383.

Hasanah, Nurlayli., et al. 2019. Meningkatkan Kemampuan Berbicara Melalui Bercerita Berbantu Media Finger Puppet Pada Anak TK Kelompok B. Masamus Journal of Primary Education, 2 (1): 32-37.

Pujiastuti, Arik Umi., et al. 2018. Analisis Kemampuan Bahasa Produktif Dan Reseptif Pada Siswa Tuna Rungu Di SDN Inklusi Kecamatan Montong Kabupaten Tuban. Prosiding Seminar Nasional Hasil Penelitian Dan Pengabdian Kepada Masyarkat III Unirow tahun 2018, 44-47.

Rambe, Riris Nur Kholidah. 2018. Penerapan Strategi Index Card Match Untuk Meningkatkan Hasil Belajar Siswa Pada Mata Pelajaran Bahasa Indonesia. Jurnal Tarbiyah, 25 (1):93-124.

Ristiyani., Roysa, Mila., dan Fakhriyah, Fina. 2017. Kelayakan Buku Santun Berbahasa Untuk Pengasuhan Berbahasa Peserta Didik TK Di Kabupaten Kudus. REFLEKSI EDUKATIKA : Jurnal Ilmiah Kependidikan, 7 (2): 159-164.

Sardila, Vera. 2015. Strategi Pengembangan Linguistik Terapan Melalui Kemampuan Menulis Biografi Dan Autobiografi: Sebuah Upaya Membangun Keterampilan Menulis Kreatif Mahasiswa. An-Nida Jurnal Pemikiran Islam, 40 (2): 110-117.

Setiawan, Dadan., et al. 2019. Kemampuan Menulis Teks Eksplanasi Dan Penguasaan Konsep Siswa sekolah Dasar Melalui Implementasi Moel Pembelajaran RADEC. Premiere Educandum Jurnal Pendidikan Dasar dan Pembelajaran, 9 (2): 130-140.

Silberman, Melvin. 2016. Active Learning: 101 Strategi Pembelajaran Aktif. Bandung: Nusamedia.

Sintia, R., Fakhriyah, Fina., dan Masfuah, Siti. 2018. Penerapan Model Direct Instruction Berbantuan Permainan Papa Saya Untuk Meningkatkan Keterampilan Proses Sains
Pada Siswa. Jurnal Prakarsa Paedagogia, 1 (1): 101-108.

Suawrtiani, Suwarni Al. 2017. Metode Index Card Untuk Meningkatkan Hasil Belajar Mapel IPS Kelas VI SD. JURNAL PENDIDIKAN: Riset Dan Konseptual, 1 (1): $1-6$.

Sudjana, Nana. 2013. Penilaian Hasil Proses Belajar Mengajar. Bandung: PT Remaja Rosdakarya.

Sugiyono. 2015. Metode Penelitian Pendidikan. Bandung: Alfabeta.

Suprijono, Agus. 2014. Cooperative Learning: Teori \& Aplikasi. Yogyakarta: Pustaka Pelajar.

Susanto, Heru. 2016. Membangun Budaya Literasi dalam Pembelajaran Bahasa Indonesia Menghadapi Era MEA. Jurnal Pendidikan Bahasa Dan Sastra Indonesia. 1 (1): 12-16.

Syarifuloh., et al. 2018. Pemerolehan Bahasa Tulis Produktif Anak Usia 2-4 Tahun. Jurnal Sastra Indonesia, 7 (2): 81-88.

Teguh, Mulyo. 2017. Gerakan Literasi Sekolah Dasar. Prosiding Seminar Nasional Tahun 2017, 18-26.

Triaji, Choirudin Lutfi., et al. 2019. Contextual Teaching And Learning Untuk Meningkatkan Keterampilan Menulis Narasi Siswa Kelas IV Sekolah Dasar. REFLEKSI EDUKATIKA : Jurnal Ilmiah Kependidikan, 9 (2): 135-140.

Wati, N,I., Utaminingsih, Sri., dan Fakhriyah, Fina. 2015. Penerapan Model Pembelajaran Berbasis Masalah (PBM) Untuk Meningkatkan Hasil Belajar IPA Siswa Di Kelas V SD Negeri Pasuruhan Pati. REFLEKSI EDUKATIKA : Jurnal Ilmiah Kependidikan, 5(1).

Yanti, Nevi Cah. 2019. Pengaruh Model Index Card Match Terhadap Hasil Belajar Tematik Siswa Kelas IV SD. Prosiding Seminar Nasional PGSD tahun 2019, 211217. 